\title{
Reception Analysis of Millennials Generation to Ads in Social Media
}

\author{
Setiya Hertanti Oktayusita ${ }^{1}$, Basuki Agus Suparno ${ }^{2}$, Christina Rochayanti ${ }^{3}$ \\ ${ }^{1}$ Hygee Home Indonesia (Novasolo Furniture) \\ Randuguang, Sariharjo, Ngaglik, Sleman Regency, Daerah Istimewa Yogyakarta 55581, Indonesia \\ ${ }^{2,3}$ Program Studi Ilmu Komunikasi, Fakultas Ilmu Sosial dan Ilmu Politik, \\ Universitas Pembangunan Nasional "Veteran" Yogyakarta \\ Jl. Babarsari 2, Tambakbayan, Yogyakarta 55281, Indonesia \\ Email: setiyaho@gmail.com ${ }^{1}$; basuki.agus@gmail.com ${ }^{2 *}$; christina.rochayanti@upnyk.ac.id ${ }^{3}$ \\ *corresponding author
}

\begin{abstract}
Gerindra presented an ad under the title of "Indonesia Bergerak Bersama Gerindra dan Rakyat version Sarjana Kerja Kerja Kerja!", but due to the use of symbols and visualization, it became viral and caused controversy in the community. This study aims to determine the opinion of millennials response after watching the ads. The research is qualitative research approach used is the analysis of the reception, the technique of collecting data is using interviews, observation and document analysis. The theory used to analyze the meaning of the audience is the encoding-decoding, reception analysis theory and new media theory. The result of this study indicate three position of millennials reception, namely a dominant, negotiated, and oppositional position. In the dominant position, it's considered as a good political ad because it successfully criticizes the government by presenting the reality of the existing problems. In the negotiating position, millennials saw the ads containing a message of criticism without a solution, in this condition millennials refused some symbols such as the use of profession symbols and titles in it, while in the opposition position, millennials considered the ads irrelevant and interpret it as a black campaign. There are several factors that become the benchmark of the millennials in perceiving that ads in social media like the character of millennials, education background, job, experience and view or tendencies to political parties. This research contributes in the form of policy recommendations to the Gerinda Party to pay more attention to solutions to criticism of advertising so as not to cause new problems. Keywords: Advertising; Millennial Generation; Reception Analysis
\end{abstract}

\begin{abstract}
Abstrak
Gerindra mempresentasikan iklan dengan judul "Indonesia Bergerak Bersama Gerindra dan Rakyat versi Sarjana Kerja Kerja!", tetapi karena penggunaan simbol dan visualisasi, iklan tersebut menjadi viral dan menyebabkan kontroversi di masyarakat. Penelitian ini bertujuan untuk menentukan pendapat tanggapan milenial setelah menonton iklan tersebut. Menggunakan pendekatan penelitian kualitatif yang menganalisis penerimaan, teknik mengumpulkan data adalah dengan wawancara, pengamatan dan analisis dokumen. Teori yang digunakan untuk menganalisis persepsi penonton adalah pengkodean-decoding, teori analisis penerimaan dan teori media baru. Hasil penelitian ini menunjukkan tiga posisi penerimaan milenial, yaitu posisi dominan, dinegosiasikan, dan oposisi. Dalam posisi dominan, iklan dianggap bersifat politik yang baik karena berhasil mengkritik pemerintah dengan menyajikan realitas masalah yang ada. Dalam posisi negosiasi, generasi milenial melihat iklan yang berisi pesan kritik tanpa solusi, dalam kondisi ini generasi milenial menolak beberapa simbol seperti penggunaan simbol profesi dan judul di dalamnya, sementara dalam posisi oposisi, generasi milenial menganggap iklan tersebut tidak relevan dan menafsirkannya sebagai kampanye hitam. Ada beberapa faktor yang menjadi tolok ukur generasi milenial dalam memahami bahwa iklan di media sosial seperti karakter milenial, latar belakang pendidikan, pekerjaan, pengalaman, dan pandangan atau kecenderungan terhadap partai politik. Penelitian ini berkontribusi dalam bentukrekomendasi kebijakan kepada Partai Gerinda untuk lebih memperhatikan solusi kritik terhadap iklan agar tidak menimbulkan masalah baru.
\end{abstract}

Kata Kunci: Iklan; Generasi Milenial; Analisis Resepsi

\section{Introduction}

The development of information and communication technology in the current era of globalization has a major influence on aspects of people's lives, including in communicating and seeking information. The hig $h$ rate social media usage in Indonesia is used by several parties as an advertising 
media. Advertising is a promotional tool that is widely used to provide information about the benefits or advantages of products. The current advertising activity is not only carried out by producers or service providers, but also political parties and leaders who have certain interests, social media is now also used for campaign.

The Gerindra Party recently released a campaign video under the title of Indonesia Bergerak Bersama Gerindra dan Rakyat versi "Sarjana Kerja Kerja Kerja!" by raising the issue of employment that faced by millennial generation. The 61-second video on December 27, 2018 at 09:00 AM has been seen 348,000 times. Gerindra Party ads basically tell an architectural scholar with magna cumlaude rank who has a problem in getting a job. Ads look a little bit sensitive because this ad involved a several jobs such as online motorcycle drivers, photographers, doormans, and valet parking services. Lately this ad caused a controversy because its considered degrading and detrimental to some parties, which has its own interpretation among millennials (Boer, 2013).

Millennials are individual who born in the early 1980s and they are the children of baby boomers, more specifically this generation are those who born between 1980 and 2000 (Faisal, 2017:9). Some of the criteria inherent in the millennial generation are full of visionary, innovative ideas and also has a tendency to use technology and emphasize work performance. The selection of millennial generation as a subject in the study is because the millennial generation is very close to technology especially the internet, has a more open communication and view pattern and very reactive to environmental changes that occur around it. Yogyakarta was chosen as the location of the study because Yogyakarta has a large number of millennial generations with diverse cultural backgrounds (Pramudyo, 2012), it will lead to diverse attitudes and thoughts. Saputra, Fajar, and AR (2017) researched the analysis of the reception for the governor election campaign film through social media, which stated that the audience received messages from Ahok-Djarot's campaign ad about diversity in a hard and straightforward way, while the Anies-Sandi campaign clan tended to The audience is interpreted as more egalitarian and displays the issue of SARA through the perspective of harmony, tolerance, and tolerance. However, Anies-Sandi's campaign ad does not present a clear message so that it still seems conceptual. Another research on advertising was carried out by Purwaningsih and Fardila (2018) which resulted in the influence of the Mars Party Perindo advertisement, which generated trust and sympathy and support from the viewing community. Penelitian yang dilakukan oleh Addasuqi (2015) menghasilkan bahwa tidak ada pengaruh antara iklan politik dengan pengambilan keputusan, namun terdapat pengaruh antara persepsi dan pengambilan keputusan.

From the explanation above, there is an interesting phenomenon to be investigated regarding the meaning of the millennial generation to an ads with title Indonesia Bergerak Bersama Gerindra dan Rakyat version Sarjana Kerja Kerja Kerja!" in social media. The informant in this study is a millennial generation who have seen the ads. This research was conducted on the basis of the controversy that come from a different meaning from advertising messages by community and several existing figures. In addition to seeing the position of the millennial generation as the target of the advertisement, this research is expected to be used as a study by advertisers to create a better ad. The objectives of this study include analyzing the millennial generation's meaning in advertising and also analyzing the position of the visualization of the message that received by millennial generation informants from the advertisement.

\section{Encoding - Decoding}

Encoding-decoding is a model that developed by Stuart Hall, as the audience process consumes and produces meaning in the process of receiving 
and consume a mass media content. Driven by the development of new media in the study of British culture, this encoding-decoding model of Stuart Hall became a pioneer of audience reception analysis studies. From Hall's concept of encoding-decoding the field of media studies has undergone a major paradigm shift, where the meaning in the process of mass communication changed from text to textual relations with the audience (Littlejohn \& Foss, 2009: 555). Encoding is the process of securing information by making it unreadable without the help of special knowledge (Wijaya \& Rahmat, 2012).

Hall explained that basically meaning is encoded by the sender and decoded by the recipient and the encoded meaning can be translated into something different by the recipient. That means, senders encode meaning in messages according to their perceptions and goals. The focus of the encoding-decoding model is on the relationship between media messages that constructed by media producers, and by the way of message that constructed by the audience. Encoding and decoding are interrelated because both are focused on the same text, however certain ways of encoding do not always direct certain decoding. In this age, social class, race, gender plays an important role in providing cultural tools for decoding. According to Stuart Hall, audiences decode media messages through three possible positions (Susanti, 2014: 6-7): 1) Dominant Hegemony Position, which is a situation where the audience receives the message conveyed by the media. It using the dominant cultural code in society. Both the media and the public share the same dominant culture; 2) Negotiation Position, which is a position where the audience generally accepts the dominant ideology but refuses an application in certain cases. In this case, the audience is willing to accept the dominant ideology that is of a general nature, but they will make a few exceptions in its application that are adjusted to the rules of the local culture; 3) Opposition Position, The last way that audiences do in decoding media messages is occurs when a critical audience changes or rejected the message that delivered by the media with an alternative message or code.

The encoding-decoding model by Stuart Hall is used to reveal that the meaning of the text lies between the text maker (encoder) and the reader (decoder). Encoding - decoding theory encourages diverse interpretations of media texts during the production process and reception. This theory can be interpreted as an audience process in consuming and producing meaning in the process of receiving and consumed the mass media content (Ida, 2014: 161).

\section{Reception Analysis Theory}

Reception analysis is a research method that focuses on how the audience interpret the messages that conveyed by a media. Reception analysis seeks to show that the audience is an active audience in producing a meaning of messages or code from the media. Reception studies are usually related to the study of the audience of television viewers, although it is possible to do it on other media. Media messages are always open, meaningful and also interpreted according to the recipient's context and culture (McQuail, 2011: 80).

Reception analysis theory argues that contextual factors influence the way audiences receive or read a media, such as films or television programs (Prijana, 2008). Contextual factors include elements of audience identity, perceptions of the film or genre of television programs, even including social, historical and political issues. In short, this theory places viewers or readers in the context of various factors that influence how to watch or read and create meaning from the text. In the reception analysis, a communicator will do the encoding, and the communicant will decode the message that has been conveyed by the communicator through a media. The framework that dominates the audience's research in the tradition of 
cultural studies is the paradigm of the active audience. This paradigm develops as a reaction to various studies of the audience with the inherent assumption that television viewers have a passive character, but instead want to show that the audience is active to produce meanings in their own cultural context (Littlejohn \& Foss, 2009: 66). The use of reception analysis theory as a support in the study of audiences is intended to place the audience not only as a passive but seen as a cultural agent who has its power in terms of producing meanings from the various discourses offered by the media (Suryani, 2013).

\section{New Media Theory}

The term 'new media' has been used since the 1960s and has included a growing and diverse set of applied communication technologies. The concept of new media is discussed by various studies. In the science and study of culture, new media are discussed from many sides, ranging from character to the influence of new media in social life. The previous communication theory was challenged to be able to adjust to the development of the media, besides that there also appeared various new theories based on previous theories in interpreting the new media. In the practice of communication, both by individuals, groups, organizations and countries, have used new media as a tool to support the communication process. As with print and electronic media, new media also has the ability to convey information to the target audience. Examples of new media include: Internet and website, digital television, cell phone/PDA phone, Streaming Video, and other related media (Efendi, Astuti, dan Rahayu, 20117).

According to Denis McQuail in his book Mass Communication Theory (2011: 43) the main characteristic of new media is the existence of mutual interconnection, access to individual audiences as recipients and senders of messages, interactivity, diverse uses as open characters, and their ubiquitous nature.

\section{Research Methods}

The research is qualitative with analysis of the reception method that emphasizes awareness or the way the subject understands objects and events with individual experiences. The subjects of this study is a millennial generation in Yogyakarta who had seen the advertisement. The objects in this research are the Indonesia Bergerak Bersama Gerindra dan Rakyat versi Sarjana Kerja Kerja Kerja! ads.

The technique of collecting data is using: 1) in-depth interviews with millennial generation in Yogyakarta, namely: Chitra Dwi Prastiwi (24), Liutamima Setiyo Fiqih (19), Yodi Prapeta Dewi (34), Iqbal Fadhil (21), Ahmad Zulfikar Ali Zain (21), Muhammad Abizar Algifary (23), Romano Giri Permana (22), and Inayah Nur Hanifah (20); 2) observation about Indonesia Bergerak Bersama Gerindra dan Rakyat versi Sarjana Kerja Kerja Kerja! ads; and 3) document analysis of data such as advertising related images.

Data analysis that used in this study is reception analysis by collecting data through interviews, the data collected and in accordance with the object are then analyzed, and the results of the analysis become the conclusions of this study. The validity test in this study is source triangulation techniques (Sugiyono, 2012: 274) that derived from any source.

\section{Results of Research and Discussion}

Advertising is a promotional tool that is widely used to provide information about the benefits and advantages of products. At present political parties also use advertisements to offer excellence and introduce their vision and mission. Political party advertisements are not only found in conventional mass media, but also in new media such as Gerindra Party that tries to reach millennial generation. Millennial generation as the research subject is a generation that born on 1980 to 2000. Millennials have criteria full of visionary ideas, innovative, have a tendency to use technology and prioritize work performance, 
besides this generation is also known to be more creative and trusting self that is quite high. This research is qualitative research using a reception analysis where the audience is considered active in perceiving messages and producing meaning, not just being passive individuals who accept the meaning that produced by mass media.

The encoding-decoding theory from Stuart Hall encourages diverse interpretations of media texts during the production process and reception. In other words the meaning that arises is never certain. The following are three interpretations introduced by Hall, including: dominant position, negotiating position and opposition position. Based on the results of research that conducted on eight informants who had watched the ads by using five assessment categories such as understanding the concept and content of advertising messages, informants assessment of advertisements, informants views of titles scholars and professional symbols that used in ads, solutions offered in ads, the results obtained in the form of three meaningful positions in accordance with the theory of encoding-decoding of Stuart Hall.

There were two informants who were in the dominant position, namely informant Chitra Dwi Prastiwi and Iqbal Fadhil. In this dominant position, the informant outlines the advertisement in accordance with what the advertiser wants. Chitra and Iqbal interpreted it as a good ad that describe the problem of the availability of jobs which are currently faced by many millennials, especially for fresh graduates, and the problems in the ads is accordance with the existing reality. The two informants in the dominant position said they agreed with the advertisement and did not show rejection about the category of questions that used by the researcher. In this position, millennial generation informants showed knowledge and a sense of confidence in assessing and supporting a media message.

There were five informants with negotiating meaning positions, namely Liutamima Setiyo Fiqih, Yodi Prapeta Dewi, Ahmad Zulfikar Ali
Zain and Romano Giri Permana and Inayah Nur Hanifah. The five informants indicated that they had interpreted according to what the advertiser wanted to say, but there were alternative interpretations because they did not agree with some aspects such as the solutions that they could not meet and some symbols that used such as titles and some of the profession in the ad. In this position, the millennial generation actually knows and understands the message, but provides other alternative thinking, it shows the critical attitude of the millennial generation in responding and assessing the ads.

In addition, in this study there was one informant, Muhammad Abizar Algifary, who was in the opposition. Algi provides meaning that is contrary to what is conveyed by the ad producer (encoder). Millennial generation informants at this position rate the ad as black campaign and according to him the advertisement only provides persuasive tendency without providing a solution. According to him, the advertisement must do a lot of research and be more creative especially when choosing millennial generation as a targets, because millennials have a level of education and knowledge more than the previous generation. At this position the millennial generation shows its tendency to think critically and have more knowledge to answer the questions that given by researchers.

Based on the results of the millennial generation's meaning in the ads that had describe above, there are various interpretations of the dominant meanings offered by researchers. In addition to the fact that the millennial character, diverse backgrounds ranging from education, employment, knowledge, experience and political views in this matter also have an influence in causing diverse meanings among the millennial generation.

In terms of political views, for example, two informants who were in a dominant position, namely informant Chitra Dwi Prastiwi and Iqbal Fadhil, had political views and tendencies 
towards the same political party. Chitra said she disagreed with the current government because she considered the current government is only prioritize infrastructure development aspect and put aside the quality of existing human resources, so she wanted a change. Similar to Chitra, Iqbal openly said his tendency and support for the Gerindra Party, he thinks that was a good and competent party, this was shown by an actualization, adjustment and good reputation.

As for the research carried out, the researchers obtained several findings that illustrated the meaning and understanding of the millennial generation of the bachelor version of the ads. In the advertisement, the Gerindra Party wants to describe the problem of job availability that many millennials are currently experiencing. The Gerindra Party also gave criticism to the government which was considered to have paid less attention to the problem with used "Kerja Kerja Kerja" which was identical to the current government's slogan.

Overall, the eight informants considered the advertisement is good in selecting issues or problems because it was in accordance with the existing reality, only some millennial generation informants criticized the description of the problem and the use of profession symbols and bachelor's degreesintheadvertisement.According to the informant who was in a negotiating and opposition position in an interview that had been conducted before, the advertisement required several improvements, especially in terms of the use of symbols and also solutions to the problems.

In terms of character selection and advertisement visualization, all of the informants stated that they agreed, according to them the selection of existing figures was appropriate in playing a scholar and representing the message and purpose of the advertisement. Meanwhile, for the use of a bachelor's architecture degree and the use of professional symbols that used in advertising, some informants said there were no problems in using the bachelor's degree, problems that exist in society today are likely to arise due to the views, knowledge and closeness or connection of individuals to these titles.

Regarding the word "Kerja Kerja Kerja" that used in the advertisement, all informants said there was no problem in using the word. Most informants know that the word is used by Joko Widodo and is identic to the current government. The informant responded to this as a critical message that could be used as an evaluation for the current government on the issue of the availability of jobs that aimed by Gerindra in its campaign ad.

In the Indonesia Bergerak Bersama Gerindra dan Rakyat versi Sarjana Kerja Kerja Kerja!" ads there are labor issues that currently occur in the community and are quite experienced by the current millennial generation, this is in accordance with the existing reality. Regarding the solution to the problems offered in the advertisement, most of the millennial generation informants have not been able to capture clearly the solutions offered in the advertisement, even some of them said they only caught criticism and with no solutions. After giving an assessment of the concept and content of the message in the advertisement, the informant suggested the Gerindra Party to add research to obtain accurate data, besides that it also needed to describe solutions in advertising while considering the use of symbols used such as titles and professions that have a potential to cause other problems.

Based on the results of the research that described above, it can be concluded that the differences in meaning that occur in the millennial generation informants are natural and in accordance with Stuart Hall's theory of encoding that encourages diverse interpretations of media texts during the production and acceptance process. In addition, this also supports the theory of reception analysis where the audience is currently considered active in interpreting meaning of media messages, the audience is influenced by several factors such as background, knowledge and critical mindset of objects that are owned in seeing, reading or hearing media messages. 
New media has changed an access information to be easier. One of them is the use of social media in finding the information and communication needs of the millennial generation. Apart from the use side, social media by the millennial generation, social media is also used by several producers providing goods and services as a media to advertise, even today political parties also do the same. In this study all informants agreed with the selection of social media as an advertising media that carried out by Gerindra. According to the informants, the selection of social media as an advertising medium is appropriate in reaching the target audience of advertisements, especially by considering the current trends in the use of social media, especially for the millennial generation.

The character of millennial generation that is adaptive, critical, and quickly captures information and knowledge that smells digital also influences the meaning and assessment. In this research, social media is interpreted as an advertising medium and also a communication tool in fulfilling the need for information by the public. Millennial generation informants in this study stated that through social media they could gain knowledge and watch the advertisement. In this case, the results of the study support the use of new media theory which explains that new media significantly changes people's behavior, one of which is by fulfilling audio and visual information needs.

\section{Conclusion}

Based on the results of the analysis described, the results of this study can be summarized: 1) The position of the millennial generation's meaning on the Indonesia Bergerak Bersama Gerindra dan Rakyat versi Sarjana Kerja Kerja Kerja! ads on social media produces a variety of meanings. Referring to Stuart Hall's theory, meaning is grouped into three positions, namely dominant hegemony, negotiation, and opposition; 2) The meaning of the eight millennial generations in this study is influenced by factors such as differences in background, education, work, and experience or knowledge possessed; 3) Factors of political views and the tendency of one political party to influence the millennial generation in interpreting the advertisement, this can be seen from the meaning carried out by the millennial generation in a dominant position; 4) There are two millennial generations in the dominant position. They interpreted the ads same as what the message maker want without any rejection. Both of them consider that the advertisement can reflect the reality regarding the current employment problems and assess the ad as a criticism aimed at the current government; 5) In negotiations position, there are five millennial generations. They interpreted according to what the producers wanted to convey but had other alternatives because they disagreed with some aspects of the advertisement such as the use of professional symbols and existing bachelor's degrees and the lack of solutions that raised in these advertisements; 6) There is one millennial generation in the opposition position. In this position the meaning offered by the message producer and the advertiser is rejected and interpreted in an opposite manner, millennials in this position replaced it with a new meaning, at this position the advertisement is interpreted as a black campaign which only contains criticism without any description of the solution in it. This research contributes in the form of policy recommendations to the Gerinda Party to pay more attention to solutions to criticism of advertising so as not to cause new problems.

\section{References}

Addasuqi, Achmad Syarief. (2015). Pengaruh Iklan Politik Peserta Pemilu dan Persepsi Pemilih Terhadap Pengambilan Keputusan Ditinjau Dari Tempat Tinggal dan Jenis Kelamin. Psikoborneo: Jurnal Ilmiah Psikologi, 3(2), 160-172. 
Boer, K. (2013). Manajemen Krisis di Balik Iklan-Iklan Kontroversial Milik Benetton. Interaksi: Jurnal Ilmu Komunikasi, 2(1), 94-103. $\quad$ https://doi.org/10.14710/ interaksi.2.1.94-103.

Efendi, Agus., Astuti, Puwani Indri,. \& Rahayu, Nuryani Tri. (2017). ANALISIS PENGARUH PENGGUNAAN MEDIA BARU TERHADAP POLA INTERAKSI SOSIAL ANAK DI KABUPATEN SUKOHARJO. Jurnal Penelitian Humaniora, 18(2), 12-24. $\quad$ https://doi. org/10.23917/humaniora.v18i2.5188

Faisal, Muhammad. (2017). Generasi Phi. Jakarta: Republika.

Ida, Rachmah. (2014). Metode Penelitian Studi Media Dan Kajian Budaya. Jakarta: Preada Media Group.

Littlejohn \& Foss. (2009). Teori Komunikasi: Theories of Human Communication. Jakarta: Salemba Humanika.

McQuail, Dennis. (2011). Teori Komunikasi Massa. Jakarta: Salemba Humanika.

Pramudyo, Anung. (2012). PENGARUH CITRA MEREK TERHADAP LOYALITAS MELALUI KEPUASAN SEBAGAI INTERVENING (Studi pada Mahasiswa Perguruan Tinggi Swasta di Yogyakarta). Jurnal Bisnis, Manajemen, dan Akuntansi 1(1), 1-16.

Prijana, Hadi. (2008). Penelitian Khalayak Dalam Perspektif Reception Analysis. Ilmu Komunikasi, Universitas Kristen Petra.

Purwaningsih, Y., \& Ana Fardila, U. (2018). ANALISIS SEMIOTIKA PESAN POLITIK
DALAM "IKLAN MARS PARTAI PERINDO". Translitera: Jurnal Kajian Komunikasi Dan Studi Media, 7(2), 0112. $\quad$ https://doi.org/10.35457/translitera. v7i02.589

Saputra, Muhammad Irawan., Fajar, Dewanto Putra., \& AR, M. Fikri. (2017). Iklan Audio Visual Sebagai Kampanye Politik : Analisis Resepsi Pada Film Kampanye Pemilihan Gubernur Jakarta Tahun 2017 di Media Sosial. Prosiding Konferensi Nasional Komunikasi, Jakarta: 7 Desember 2017. Hal. 594-608.

Sugiyono. (2012). Metode Penelitian Kualitatif: Kualiatif dan $R \& D$. Bandung: Alfabeta.

Suryani, Any. (2013). Analisis Resepsi Penonton Atas Popularitas Instan Video Youtube Keong Racun Sinta dan Jojoe. Jurnal The Messenger: Cultural Studies, IMC and Media, 5(1), 39-45. http://dx.doi. org/10.26623/themessenger.v5i1.142

Susanti, Billy. (2014). Analisis Resepsi Terhadap Iklan Rasisme Dalam Film. Program Studi Ilmu Komunikasi, Universitas Muhammadiyah Surakarta.

Wijaya, A. E., \& Rahmat G., D. (2012). PEMBUATAN APLIKASI ENCODE DAN DECODE BERBASIS WEB MENGGUNAKANALGORITMABASE64 UNTUK KONFIRMASI PENGIRIMAN PIN. Jurnal Teknologi Dan Komunikasi STMIK Subang, 2(1). Retrieved from http:// jurnalstmiksubang.ac.id/index.php/jtik/ article/view/42 